\title{
Udder infections with Staphylococcus aureus, Streptococcus dysgalactiae, and Streptococcus uberis at calving in dairy herds with suboptimal udder health
}

\author{
A. Lundberg, ${ }^{*} \dagger$ A-K. Nyman, ${ }^{*}$ A. Aspán, S. Börjesson, ${ }^{*}$ H. Ericsson Unnerstad, ${ }^{*}$ and K. Persson Waller ${ }^{*} \dagger^{1}$ \\ *Department of Animal Health and Antimicrobial Strategies, National Veterinary Institute, SE-751 89 Uppsala, Sweden \\ †Department of Clinical Sciences, Swedish University of Agricultural Sciences, SE-750 07 Uppsala, Sweden \\ ‡Department of Bacteriology, National Veterinary Institute, SE-751 89 Uppsala, Sweden
}

\begin{abstract}
Udder infections with Staphylococcus aureus, Streptococcus dysgalactiae, and Streptococcus uberis are common causes of bovine mastitis. To study these pathogens in early lactation, a 12-mo longitudinal, observational study was carried out in 13 herds with suboptimal udder health. The aims of the study were to investigate the occurrence of these pathogens and to identify if presence of the 3 pathogens, and of genotypes within the pathogens, differed with respect to herd, season, and parity. Quarter milk samples, collected at calving and $4 \mathrm{~d}$ in milk (DIM), were cultured for the 3 pathogens. Genotyping of staphylococcal and streptococcal isolates was performed using spa typing and pulsed-field gel electrophoresis, respectively. For each of the 3 pathogens, cows with an udder infection at calving or 4 DIM were allocated to 1 of 4 infection types: cleared (pathogen present only at calving), persistent (pathogen present in the same quarter at calving and 4 DIM), new (pathogen present only at 4 DIM), or cleared/new (pathogen present in 1 quarter at calving and in another quarter at 4 DIM). Associations between season or parity and overall occurrence of pathogens or infection types were determined using univariable mixed-effect logistic-regression models and the Fisher's exact test, respectively. The most commonly occurring pathogen was Staph. aureus, followed by Strep. dysgalactiae and Strep. uberis. Persistent infections were the most common infection type among Staph. aureus-infected cows, whereas cleared infections were the most common among Strep. dysgalactiae- and Strep. uberis-positive cows. The proportion of cows with persistent Staph. aureus infections and the proportion of cows having a Strep. uberis infection at calving or 4 DIM were higher in the multiparous cows than in primiparous cows. Infections with Strep. dysgalactiae
\end{abstract}

Received February 20, 2015.

Accepted December 4, 2015.

${ }^{1}$ Corresponding author: karin.persson-waller@sva.se were less common during the early housing season than during the late housing or pasture seasons, whereas persistent Strep. uberis infections were less common during the pasture season than during the late housing season. The relative occurrence of the 3 pathogens, infection types of each pathogen, and genotype diversity of each pathogen throughout the year or in different seasons and parities varied among the herds, indicating that underlying factors predisposing for udder infections at calving differ between herds. Genotyping of bacterial isolates gave important insight into how such infection patterns differed within and between herds. These findings emphasize the need to choose preventive strategies for each individual herd.

Key words: dairy cow, mastitis, Staphylococcus aureus, Streptococcus dysgalactiae, Streptococcus uberis

\section{INTRODUCTION}

In dairy cows, both subclinical mastitis (SCM; Svensson et al., 2006; Madouasse et al., 2010; Archer et al., 2014) and clinical mastitis (CM; Valde et al., 2004; Svensson et al., 2006; McDougall et al., 2007) are common around calving and in early lactation. Most SCM and CM are caused by IMI. In a Swedish study, Staphylococcus aureus was the most common IMI causing CM during the first month of lactation in primiparous cows, followed by Streptococcus dysgalactiae and Streptococcus uberis (Persson Waller et al., 2009), which is largely in line with the overall distribution of IMI causing CM and SCM in Sweden (Ericsson Unnerstad et al., 2009; Persson et al., 2011); these results also coincide with Norwegian studies (Waage et al., 1999; Osterås et al., 2006). Staphylococcus aureus and Strep. uberis are also important IMI in many other countries (Gianneechini et al., 2002; McDougall et al., 2007; Olde Riekerink et al., 2008). The prevalence of different IMI or occurrence of CM may, however, vary between regions of the world (Bradley et al., 2007; Nam et al., 2010) and between herds (Myllys and Rautala, 1995; Barkema et al., 1998; Osterås et al., 2006; McDougall et al., 2007). Although, 
information on the distribution of IMI at calving and in early lactation within herds in the Scandinavian countries is not available.

Within-herd parity differences in distribution of IMI around calving have, to our knowledge, not been studied recently. Moreover, studies on seasonal variation of such IMI are scarce (Fox et al., 1995). When studying the whole lactation period, however, seasonal differences in prevalence of Staph. aureus, Strep. dysgalactiae, or Strep. uberis IMI in clinically healthy udders (Osterås et al., 2006) or in cases of CM (Waage et al., 1999; Olde Riekerink et al., 2007; Ericsson Unnerstad et al., 2009) have been described.

Staphylococcus aureus, Strep. dysgalactiae, and Strep. uberis have traditionally been categorized in different groups with regard to their major reservoirs. The recent introduction of genotyping has, however, contributed new information on the epidemiology of such IMI. Staphylococcus aureus is mainly considered a contagious pathogen, but the same genotypes of Staph. aureus can be found in milk, on body sites of calves, heifers, and cows, and in their immediate environment (Capurro et al., 2010). The presence of environmental reservoirs has also been suggested by others (Sommerhäuser et al., 2003), although the variation in Staph. aureus genotypes within- and between-herds is often small (Sabour et al., 2004; Mørk et al., 2005; Lundberg et al., 2014a).

Streptococcus uberis is mostly considered an environmental pathogen, and its risk factors for mastitis differ from those for Staph. aureus (Barkema et al., 1999). Studies also indicate that the genetic variation between Strep. uberis isolates is considerable both within- and between-herd (Baseggio et al., 1997; Douglas et al., 2000; Lundberg et al., 2014b). Within-herd spread of the same genotype of Strep. uberis has also been described (Zadoks et al., 2003).

Relatively few recent studies on Strep. dysgalactiae have been performed, and those that have indicate that it may act either as a contagious or environmental pathogen (Todhunter et al., 1995; Barkema et al., 1999). The genotype variation of Strep. dysgalactiae isolates from CM cases is larger than for Staph. aureus (Lundberg et al., 2014a), but smaller than for Strep. uberis (Lundberg et al., 2014b). Few recent studies have evaluated risk factors for Strep. dysgalactiae IMI, and none of those have been performed in the Scandinavian countries. A Dutch study on risk factors for CM indicate that Staph. aureus and Strep. dysgalactiae can have similar patterns of infection (Barkema et al., 1999).

To decrease the incidence of mastitis in early lactation, new IMI must be prevented. Today, preventive control measures are mainly based on the most common risk factors for the most common pathogens present in a herd. Staphylococcus aureus, Strep. dysgalactiae, and Strep. uberis are, however, probably able to spread both in a contagious and environmental way, and some farms experience long-term mastitis problems despite well-implemented preventive measures. To improve recommendations on preventive measures, a better understanding of variation within and among herds in Staph. aureus, Strep. dysgalactiae, and Strep. uberis infection patterns (i.e., occurrence of IMI close to calving in regards to bacterial species and genotypes within species) is needed. Therefore, the aims of the current study were to investigate (1) the presence of Staph. aureus, Strep. dysgalactiae, and Strep. uberis IMI and genotypes within species at and just after calving in large freestall barn-housed herds with suboptimal udder health (defined by the proportion of cows with SCM), and (2) whether the infection patterns identified differ with respect to herd, season (pasture, early housing, late housing), and parity.

\section{MATERIALS AND METHODS}

\section{Herd Selection}

Herds were selected on the basis of data from the Swedish Official Milk Recording Scheme (SOMRS; Växa Sverige, Stockholm, Sweden) in 2009 and 2010, a scheme in which approximately $80 \%$ of all Swedish dairy herds and dairy cows are enrolled. Criteria for inclusion in the study were to have (1) lactating cows in freestall barns, (2) a herd size of 75 to 250 cows, (3) conventional milking in a milking parlor, (4) a herd with at least $75 \%$ Swedish Holstein $(\mathbf{S H})$ or Swedish Red (SR) breeds, and (5) year-round calving. In addition, the herds should be among the $50 \%$ of the dairy herds enrolled in the SOMRS with the lowest average proportion of cows in udder health classes 0 to 2 , corresponding to a cow composite SCC below 130,000 cells/ $\mathrm{mL}$ at 2 or 3 consecutive monthly milk recordings, during the selection year. Furthermore, the herds should have recorded cases of CM caused by Staph. aureus and streptococci. Due to practical reasons, only herds situated in the southern third of Sweden were contacted. The owners of eligible herds $(n=86)$ were contacted by letter in late 2010 or early 2011 and shortly thereafter by phone until 20 herds were recruited. Due to practical and economic reasons, it was not possible to include a larger number of herds in the study. The herd owners received in-depth information about the project and were informed that no results would be released until the end of the study unless Streptococcus agalactiae IMI was found. Farm visits were scheduled in January to March 2011 when the owner or herd manager or staff 
were present. They received thorough instructions on aseptic milk sampling and all necessary sampling material at the time of the visit. Collection of milk samples started thereafter and continued for 12 mo. During the year, the quality of the milk sampling was regularly controlled and the inclusion of as many eligible cows (i.e., cows with even-numbered ear-tags) as possible was also controlled using data from the SOMRS. When necessary, the farmers were contacted to encourage continued sampling or to give advice on how to improve the sampling technique.

\section{Cow Selection and Milk Sampling}

Due to economic reasons, sampling was limited to cows with even-numbered ear tags. Herd personnel collected udder quarter milk samples (QMS) twice from each cow in the study. The first sampling was performed before the first milking after calving and the second at 4 DIM. Only 1 calving per cow was included. Milk samples collected on Sunday to Thursday mornings were sent immediately to the National Veterinary Institute (Uppsala, Sweden) by postal mail. Samples collected Thursday evening to Saturday were refrigerated and sent on the earliest possible occasion after the weekend.

\section{Bacteriological Culturing}

All milk samples were frozen upon arrival to the National Veterinary Institute. Within 4 wk after collection the samples were thawed and mixed thoroughly. Ten microliters of milk was cultured overnight on $5 \%$ bovine blood agar supplemented with $0.05 \%$ esculine (National Veterinary Institute). Plates were mainly evaluated for growth of Staph. aureus, Strep. dysgalactiae, and Strep. uberis using accredited methods at the National Veterinary Institute as described by Ericsson Unnerstad et al. (2009). In the process, colonies suspected to be streptococci or staphylococci that were identified as Strep. agalactiae, CNS, or coagulase-positive staphylococci other than Staph. aureus (CPS) were also registered. Growth of other colonies (e.g., Trueperella pyogenes and gramnegative bacteria) were identified on the basis of colony morphology and the results of catalase- and potassium hydroxide tests, where appropriate. A sample was classified as contaminated if 3 or more species were isolated and none of the species was Staph. aureus, Strep. dysgalactiae, or Strep. uberis. According to routines at the National Veterinary Institute, a milk sample was classified as bacteriologically positive if at least $100 \mathrm{cfu} /$ $\mathrm{mL}$ of Staph. aureus or at least $300 \mathrm{cfu} / \mathrm{mL}$ of any of the other pathogens was isolated. All isolates of Staph. aureus, Strep. dysgalactiae, and Strep. uberis were frozen in trypticase soy broth containing $15 \%$ glycerol and stored until genotyping was performed.

\section{Genotyping of Bacterial Isolates}

A selection of bacterial isolates was genotyped. Staphylococcus aureus isolates were spa typed using primers spa1113f and spa1514r (Mellmann et al., 2006) or primers spa239f and spa1717r (Hallin et al., 2009). Assignment of spa types was conducted using BioNumerics software (BioNumerics Version 7.1; Applied Maths Inc., Austin, TX).

Streptococcus dysgalactiae and Strep. uberis isolates were genotyped using pulsed-field gel electrophoresis as described in Lundberg et al. (2014b), and analysis of the macro-restriction patterns was performed using BioNumerics software. Isolates from each herd and of each species were analyzed separately. Isolates with identical banding patterns were considered to be of the same pulsotype, and isolates with up to 3 bands difference were considered to be of the same cluster. Each cluster was identified by the capital letter of the herd followed by a lowercase letter (e.g., Aa, Ab, Ba, Bb) for Strep. dysgalactiae, or by a capital letter (e.g., AA, AB, BA, BB) for Strep. uberis. Pulsotypes within clusters were identified by a digit following the cluster name (e.g., Aa1, Aa2, AA1, AA2).

\section{Definition of Infections at Cow Level}

Each cow was categorized as mono-infected, coinfected, infected with other bacteria or contaminated, or negative (NEG). Mono-infected cows had growth of either Staph. aureus, Strep. dysgalactiae, or Strep. uberis in one or more quarters on at least one sampling. If more than one of the species Staph. aureus, Strep. dysgalactiae, and Strep. uberis was found in the same cow, the cow was defined as co-infected. A cow was also considered co-infected if Strep. agalactiae or Trueperella pyogenes were found in combination with Staph. aureus, Strep. dysgalactiae, or Strep. uberis. Cows defined as NEG had no bacterial growth in any QMS, or a maximum of 4 contaminated QMS out of the total 8 QMS taken from each cow. The latter cows in the NEG group were included if no significant difference was noted in cow SCC at the first monthly milk recording after calving between cows with no bacterial growth in any QMS and cows with a maximum of 4 contaminated QMS out of the total 8 QMS taken from each cow. Finally, cows infected with other pathogens (mainly CNS) or having more than 4 contaminated QMS were grouped together. 
Each mono-infected (Staph. aureus, Strep. dysgalactiae, or Strep. uberis) cow was allocated to one of the following infection types. If the pathogen was present only at calving the infection was defined as cleared (CLE); the pathogen present in the same quarter at calving and 4 DIM defined the infection as persistent (PER). Pathogens present only at 4 DIM defined the infection as new (NEW). If a pathogen was present in one quarter at calving and in another quarter at 4 DIM, the infection was defined as CLE/NEW. The same infection types were also specified for co-infected cows for each of the 3 species; thus, 1 cow could be included more than once when co-infected.

\section{Selection of Bacterial Isolates for Genotyping}

For each herd, milk isolates were selected for genotyping such that a maximum of 3 isolates of each bacterial species from each of the following groups of cows: primiparous with CLE infections, primiparous with NEW infections, multiparous with CLE, and multiparous with NEW infections. The isolates originated from both mono-infected and co-infected cows. For the cows with PER infections, a maximum of 6 isolates (3 cows) per herd, species, and parity group was selected. If more than the maximum number of isolates per group were available, randomizing software was used to select the isolates.

\section{Cow and Herd Data}

Individual records for all cows in the participating herds were obtained from the SOMRS and the Swedish Animal Disease Recording System (Växa Sverige, Stockholm, Sweden). The records included information about breed, calving dates, parity, culling, cases of veterinary-treated clinical mastitis (VTCM), and results from monthly milk recordings (milk yield and SCC).

\section{Data Editing and Statistical Analyses}

Results from herds $(\mathrm{n}=13)$ that submitted samples from at least $75 \%$ of the cows with even-numbered ear tags during the 12-mo sampling period were included in the data analyses. Descriptive data of included herds and sampled cows is presented in Table 1. The year of selection, the national average annual milk production was $9,260 \mathrm{~kg}$ of ECM per cow, and the national average (geometric mean) of bulk milk SCC delivered to dairies was 194,000 cells/mL. The average (arithmetic mean) cow composite SCC the year of selection was 248,000 cells/mL based on SOMRS results. Individual cows were included in the analyses $(\mathrm{n}=736)$ if sampled both at calving and 4 DIM; all other cows were excluded from data analyses. The statistical analyses were performed using STATA 13.1 (StataCorp LP, College Station, TX).

Associations Between Infection Type and Udder Health Parameters. To investigate if infection type was of importance for udder health in early lactation, the influence of infection type of mono-infected cows $(\mathrm{n}=232)$ on SCC at the first monthly milk recording within $31 \mathrm{~d}$ after calving and VTCM occurring within $31 \mathrm{~d}$ after calving was evaluated for each bacterial species in comparison with NEG cows ( $\mathrm{n}=$ 152). This was done using multivariable mixed-effect linear-regression models.

Cow SCC at the first monthly milk recording was used as the outcome variable and infection type at sampling (NEG, CLE, PER, NEW, and CLE/NEW) as the explanatory variable. To obtain normally distributed residuals, SCC was transformed using the Box-Cox power transformation, $\left(\mathrm{SCC}^{-0.2134289}-1\right) /-0.2134289$. Because of their possible association with SCC, the models also included the independent variables cow breed, parity, milk yield, and DIM at monthly milk recordings. Collinearity between the independent variables was assessed pairwise by Spearman rank correlations. When proof of collinearity $(\mathrm{r} \geq 0.70)$ existed, the variable with the lowest $P$-value in the univariable analysis was selected. The continuous explanatory variables were assessed if they were linearly related to the outcome by visual examination (using the "lowess" command in Stata), and, if not, they were either categorized using percentiles as cut-offs or transformed. A manual, stepwise-backward model-selection procedure was used to reduce the full multivariable models, and only variables with a $P$-value of $<0.05$ were included. Two-way interactions between the significant main effects were tested. Least squares means were calculated for the variables included in the final models. For continuous variables, the least squares means were calculated for respective quartiles 1 to 3 . The model fit of the multivariable analyses was tested by visual examination of diagnostic plots according to Dohoo et al. (2010).

Associations between infection type and VTCM within $31 \mathrm{~d}$ after calving were investigated using univariable mixed-effect logistic-regression models, with VTCM as outcome variable and infection type at sampling as explanatory variable. Multivariable models were not performed due to too few observations.

Other Analyses. The influence of season [late housing (January-April), pasture (May-August), early housing (September-December)] and parity (primiparous, multiparous) on the proportion of cows infected with 
LUNDBERG ET AL.

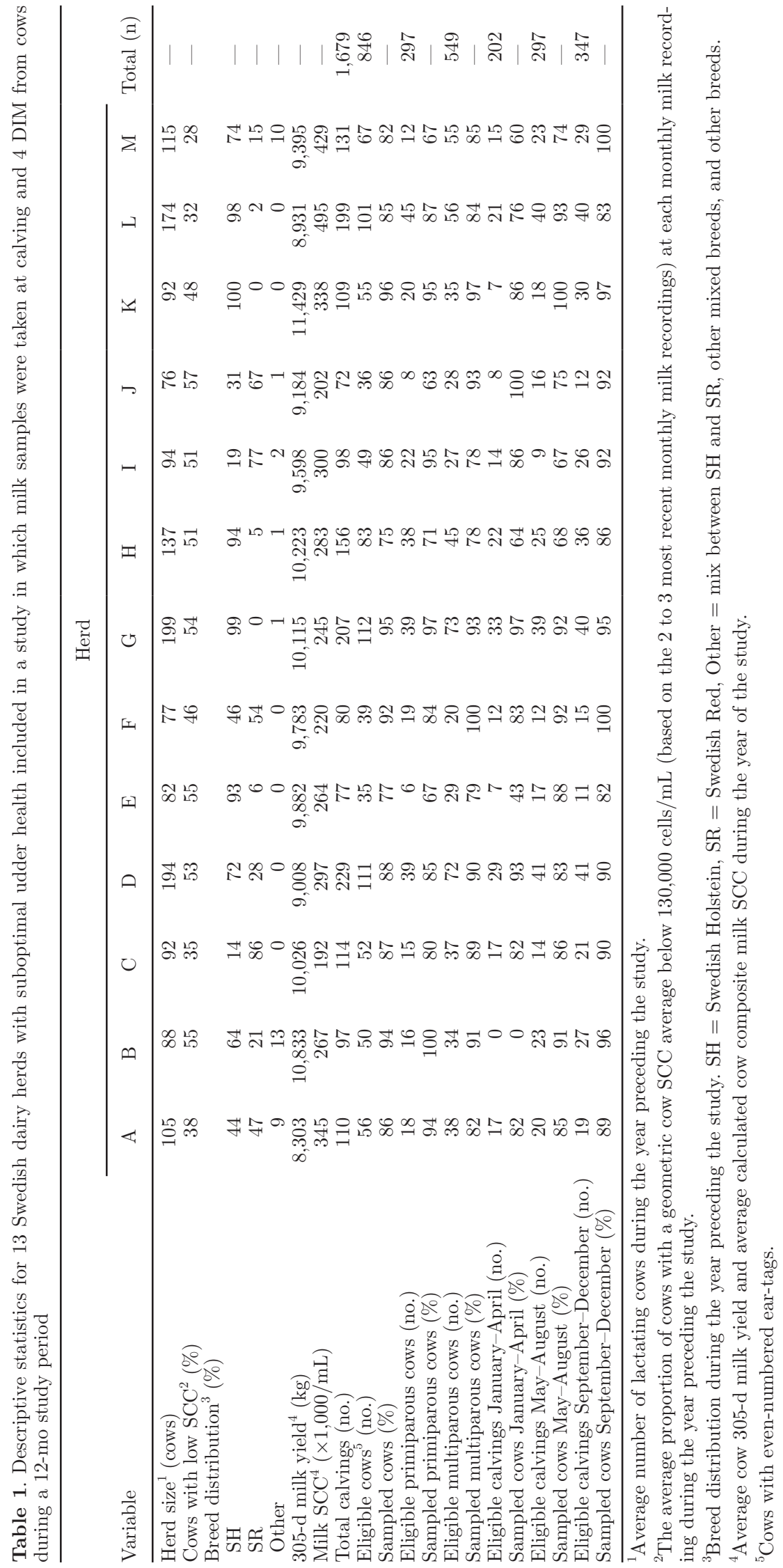


Staph. aureus, Strep. dysgalactiae, or Strep. uberis on at least one sampling was calculated using univariable mixed-effect logistic-regression models. Associations between season or parity and infection type within each bacterial species were investigated using the Fisher's exact test.

In all mixed-effect linear- and logistic-regression models, herd was used as a random effect. An identity covariance structure (equal variances for random effects, all covariances are zero) was used. If the random effect was not significant, ordinary linear regression models were used.

The infection patterns within each herd are presented graphically, and descriptive statistics included. Further statistical analyses on infection patterns were not possible due to the small numbers of observations within some herds.

In analyses and descriptions of differences between seasons and parities, as well as in descriptions of herds, the categorization into mono- and co-infections was disregarded, except when differences between monoand co-infections were specifically described. Thus, one individual cow could be included in the description of more than one bacterial species.

\section{RESULTS}

Thirteen herds and 736 cows met the inclusion criteria at herd and cow levels, respectively. Seven herds failed to complete the whole sampling period, due to owners lack of motivation, problems with logistics, or too heavy on-farm workload, and were excluded. Exclusions on the cow level were mainly explained by missed sampling at one of the samplings. Descriptive data on included herds and sampled cows are given in Table 1. The average annual 305-d milk production and calculated cow composite SCC at monthly milk recordings in all SOMRS-affiliated herds during the study period were $9,500 \mathrm{~kg}$ of ECM and 255,000 cells/mL, respectively.

\section{Bacterial Findings on the Cow Level}

Of 736 cows sampled both at calving and 4 DIM, 130 had Staph. aureus mono-infection, 57 had Strep. dysgalactiae mono-infection, and 45 had Strep. uberis mono-infection, whereas 152 cows were classified as NEG. Among the remaining cows, 84 were co-infected (44 Staph. aureus and Strep. dysgalactiae, 14 Staph. aureus and Strep. uberis, 4 Staph. aureus, Strep. dysgalactiae, and Strep. uberis, 11 Strep. dysgalactiae and Strep. uberis, 4 Strep. dysgalactiae and T. pyogenes, 2 Staph. aureus and Strep. agalactiae, 1 Staph. aureus and T. pyogenes, 1 Strep. uberis and T. pyogenes, 1 Staph. aureus and CPS, 1 Strep. dysgalactiae and CPS, 1 Strep. uberis and CPS) and 268 cows were infected with other bacteria or contaminated in more than 4 udder quarter samples.

Descriptive statistics of overall cow-level occurrence of the 3 pathogens (i.e., both mono- and co-infected cows), categorized by infection type, parity, and season, are presented in Table 2. Staphylococcus aureus-infected

Table 2. Incidence of Staphylococcus aureus, Streptococcus dysgalactiae, and Streptococcus uberis IMI at calving and 4 DIM in all cows, and divided by parity and season, in 13 Swedish dairy herds with suboptimal udder health

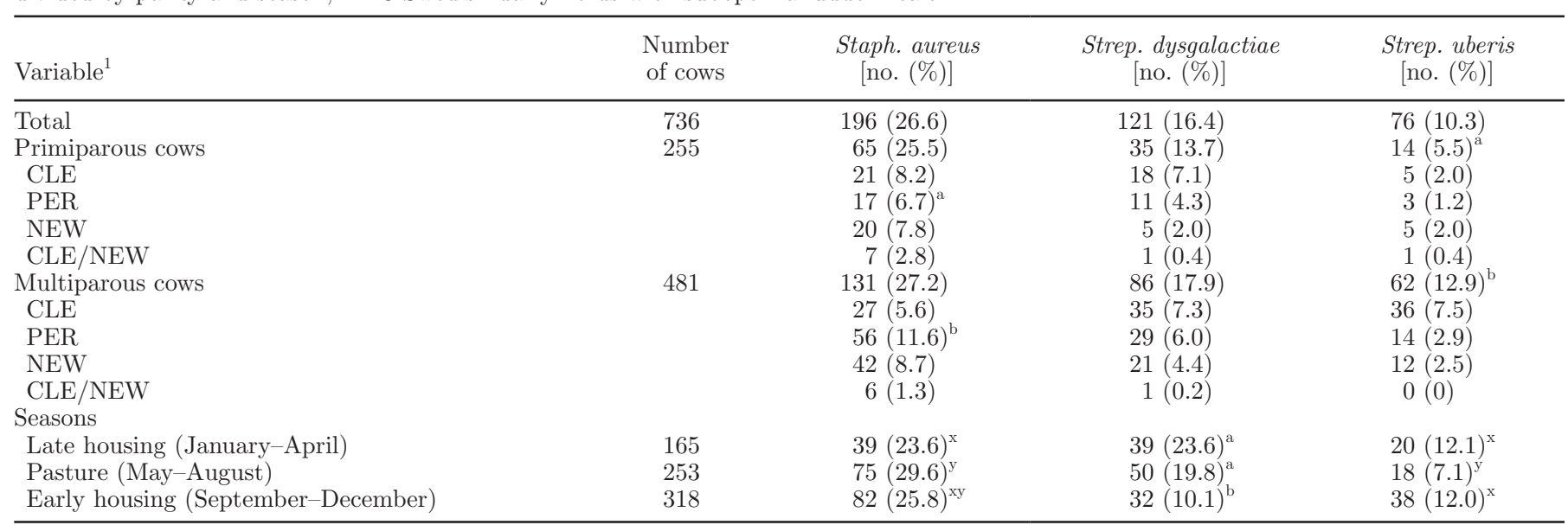

${ }^{\mathrm{a}, \mathrm{b}}$ Proportions within columns with different superscripts differ between parities or seasons $(P<0.05)$.

${ }^{\mathrm{x}, \mathrm{y}}$ Proportions within columns with different superscripts tend to differ between seasons $(0.10>P>0.05)$.

${ }^{1} \mathrm{CLE}=$ culture-positive at calving and culture-negative at 4 DIM; PER = culture-positive for the same pathogen at calving and 4 DIM; NEW $=$ culture-negative at calving and culture-positive at 4 DIM; CLE/NEW = culture-positive in different quarters at calving and 4 DIM. Both mono-infected and co-infected cows were included. 
cows were most common, followed by cows infected with Strep. dysgalactiae or Strep. uberis. Persistent infections were the most common infection type among Staph. aureus-infected cows, and CLE was the most common infection type among Strep. dysgalactiae- and Strep. uberis-infected cows.

The proportion of Staph. aureus-infected cows was similar for primiparous and multiparous cows, but PER Staph. aureus infections were more common in the latter $(P=0.029)$. Streptococcus uberis was more common in multiparous cows than in primiparous cows $(P=$ $0.001)$. No significant difference was noted among parities among the cows positive for Strep. dysgalactiae ( $P$ $>0.05)$.

The proportion of Staph. aureus-infected cows tended to be higher in the pasture season than in the late housing season $(P=0.089)$. The proportion of Strep. dysgalactiae-infected cows was lower in the early housing season compared with the rest of the year $(P<0.001)$. Overall, the proportion of Strep. uberis-infected cows tended to be lower $(P=0.07)$ in the pasture season compared with the 2 other seasons. Persistent Strep. uberis infections were more common in the late housing season compared with the pasture season $(P=0.014$; data not shown).

\section{Associations Between Infection Type and Udder Health Parameters}

The SCC was higher in cows with NEW and PER Staph. aureus infections than in NEG cows, and all cows with Strep. dysgalactiae and Strep. uberis infections had higher SCC than NEG cows (Table 3). Of the independent variables, parity (Strep. uberis models), DIM (Staph. aureus and Strep. dysgalactiae model), milk yield (Strep. uberis models), and breed (Staph. aureus model) were associated with SCC.

The incidence of VTCM did not differ between Staph. aureus-infected cows and NEG cows or between Strep. dysgalactiae-infected cows and NEG cows when all infection types were included (Table 4). When analyzing each infection type within species, significantly more cows with PER Staph. aureus infections had VTCM compared with NEG cows. Cases of VTCM were more common among Strep. uberis-infected cows than among NEG cows $(P<0.05)$. More cows with PER and NEW Strep. uberis infections had VTCM compared with NEG cows, and a similar tendency was observed for cows with CLE infections. Although CLE Staph. aureus infections were not significantly associated with SCC or VTCM, cows with this infection type were also included in the following presentation of results given their possible importance for the overall bacterial load of Staph. aureus in the herds.

\section{Herd Variation in Bacterial Findings}

General Aspects. The total proportion of Staph. aureus-infected cows per herd ranged from 12 to $45 \%$ (Figure 1). Most herds had cows with PER, CLE, and NEW infections, but 1 herd (E) had no cows with CLE infection, and 3 herds (B, C, and J) had no NEWinfected cows. Persistent infections were common in herd $\mathrm{F}$ (31\% of the cows), but uncommon in herds $\mathrm{A}$ and M (approximately $2 \%$ of the cows per herd).

The total proportion of Strep. dysgalactiae-infected cows per herd ranged from 3 to $35 \%$ (Figure 1). Cleared and PER infections were found in all herds except in herd E, where all Strep. dysgalactiae infections were NEW. Cows with NEW infections were not found in 3 herds ( $\mathrm{C}, \mathrm{F}$, and $\mathrm{J}$ ), and NEW infections were less common than CLE and PER infections in 4 other herds $(\mathrm{A}, \mathrm{G}, \mathrm{H}$, and $\mathrm{I})$.

The total proportion of Strep. uberis-infected cows per herd ranged from 2 to $24 \%$ (Figure 1), and reached $10 \%$ or more in fewer than half of the herds (A, G, I, K, $\mathrm{L}$, and $\mathrm{M}$ ). Persistent infections occurred in less than $1 \%$ of the cows in 6 of the herds (B to E, J, and $\mathrm{K}$ ). Cleared Strep. uberis infections were found in all but 3 herds (C, E, and F). In herds C and F, Strep. uberis NEW infections were not found.

The relative distribution between the 3 pathogens varied in the herds (Figure 1). In most of them, Staph. aureus was the most common pathogen, except for herds A and I, where Strep. dysgalactiae was most common. In herds D and G, Staph. aureus and Strep. dysgalactiae were both prevalent, but the proportion of Strep. uberis-infected cows was low. In herd L, Staph. aureus and Strep. uberis infections occurred equally often and were more common than Strep. dysgalactiae infections, which were only found in a few cows. In herd $\mathrm{K}$, the prevalences of all 3 pathogens were similar.

Parity Effects. The herd distribution of bacterial findings for cows of different parity are presented in Supplementary Figure S1 (http://dx.doi.org/10.3168/ jds.2015-9487). The relative distribution of proportions of Staph. aureus- or Strep. dysgalactiae-infected cows, or cows of different Staph. aureus or Strep. dysgalactiae infection types, in primiparous and multiparous cows varied among the herds. The proportion of Strep. uber$i s$-infected cows was, however, numerically higher in multiparous than primiparous cows in all herds except M. In 7 herds (B to $\mathrm{F}, \mathrm{H}$, and J), no primiparous cows were infected with Strep. uberis. Multiparous cows with Strep. uberis infections were found in all herds.

Seasonal Variations. The seasonal variation of the proportions of cows infected with the 3 pathogens is presented in Supplementary Figure S2 (http://dx.doi. org/10.3168/jds.2015-9487). The proportion of cows 
UDDER INFECTIONS AT CALVING IN HERDS

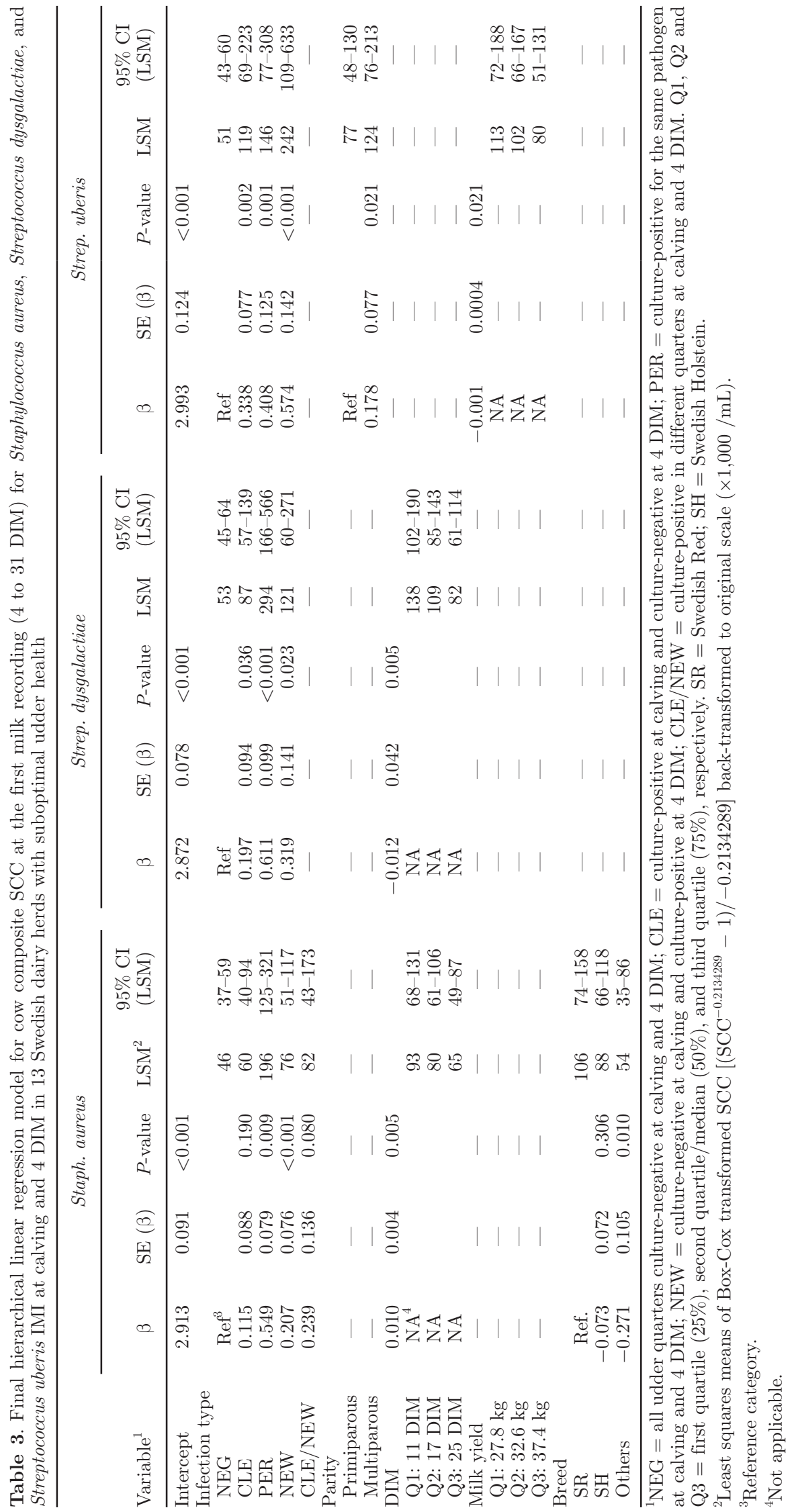




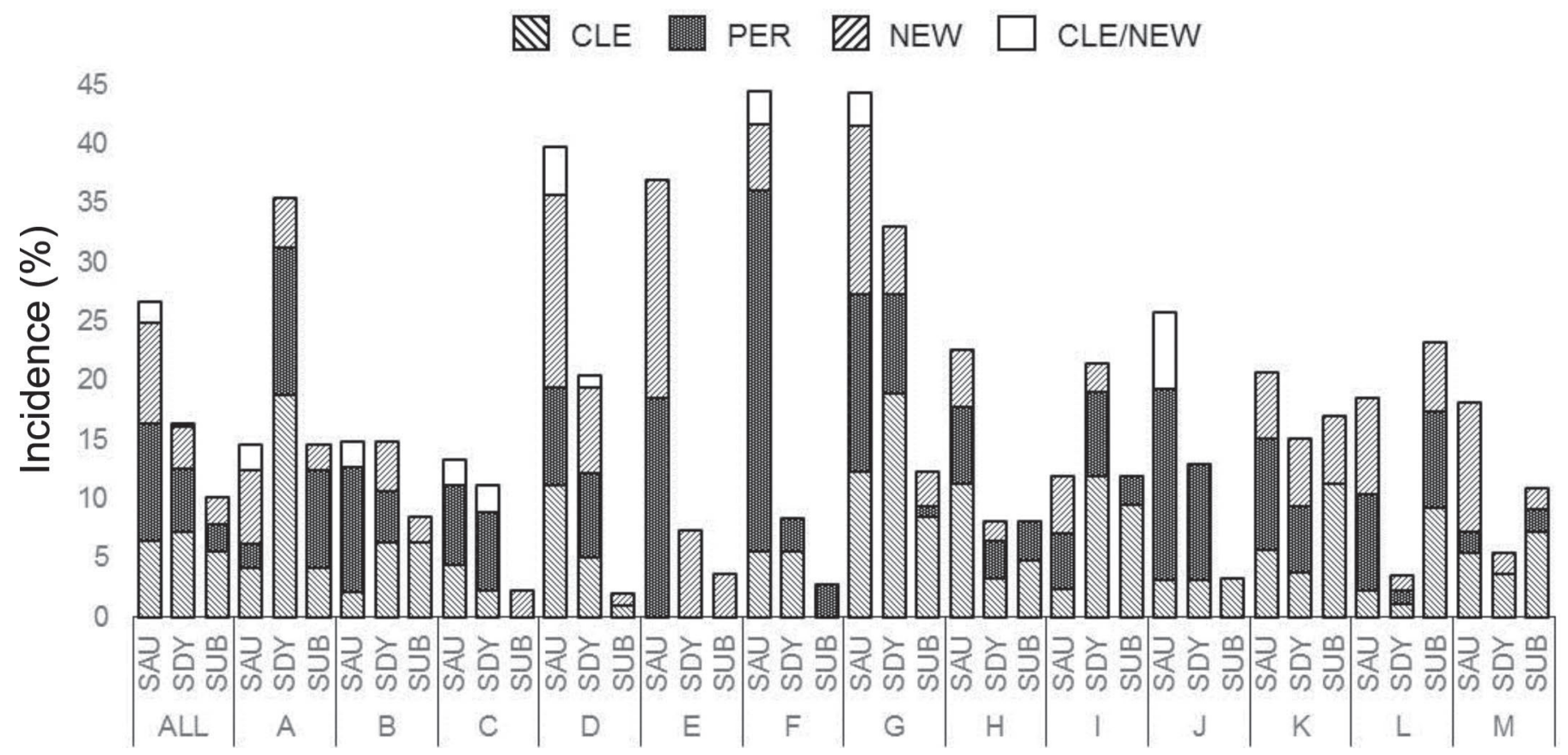

Figure 1. Incidence of Staphylococcus aureus (SAU), Streptococcus dysgalactiae (SDY), and Streptococcus uberis (SUB) IMI among all cows (ALL) and among cows in each herd (A-M). Each bar is divided into infection types based on if samples were positive only at calving (CLE), at calving and 4 DIM (PER), only at 4 DIM (NEW), or in different udder quarters at calving and 4 DIM (CLE/NEW). Both mono-infected and co-infected cows were included.

Table 4. Incidence of veterinary-treated clinical mastitis (VTCM) in the first month of lactation according to IMI at calving and 4 DIM in 13 herds with suboptimal udder health

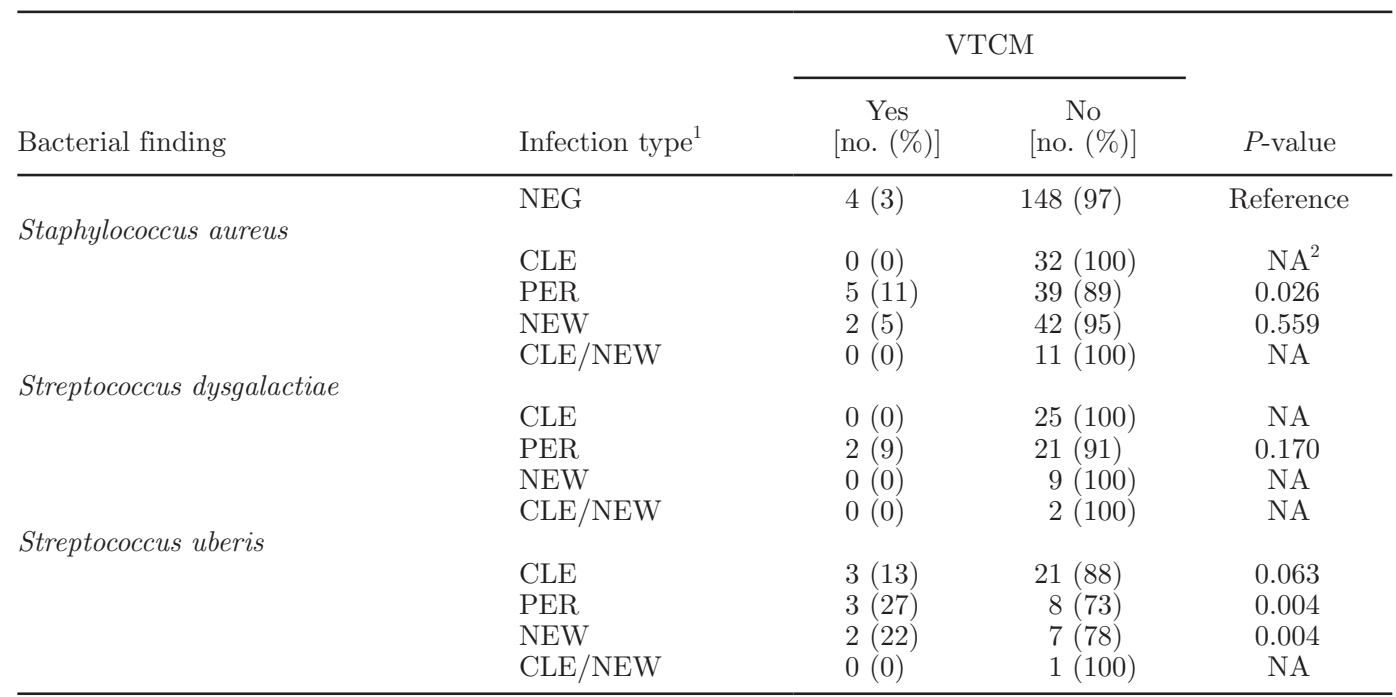

${ }^{1} \mathrm{NEG}=$ all udder quarters culture-negative at calving and 4 DIM; CLE = culture-positive at calving and culture-negative at 4 DIM; PER = culture-positive for the same pathogen at calving and 4 DIM; NEW = culture-negative at calving and culture-positive at 4 DIM; CLE/NEW = culture-positive in different quarters at calving and 4 DIM.

${ }^{2}$ Not applicable (i.e., none of the cows of a certain infection type had VTCM). 
infected with Staph. aureus varied between seasons in most of the herds, except in herd H. Herd I was the only herd that had the highest proportion of Staph. aureus-infected cows in the late housing season.

No clear seasonal pattern was noted for Strep. dysgalactiae-infected cows at herd level. In 4 herds (C, E, F, and L), Strep. dysgalactiae was not found in the early housing season, and in 3 herds (E, J, and $\mathrm{M}$ ) the pathogen was not found in the late housing season. Streptococcus dysgalactiae-infected cows were found during the pasture season in all herds except C.

A seasonal trend emerged for Strep. uberis-infected cows. No cows were Strep. uberis-infected in the late housing season in herds B, C, D, E, F, I, J, and K. However, in 2 other herds ( $\mathrm{L}$ and $\mathrm{M}$ ), the late housing season was the season with the highest proportion of Strep. uberis-infected cows. In the early housing season, Strep. uberis was found in all herds except herd E.

\section{Genotype Patterns of the Bacterial Isolates}

Staphylococcus aureus spa Types. In total, 160 isolates were spa typed and 13 spa types were identified (Table 5). Six isolates could not be typed using the 2 sets of primers. The most common spa types were t529 $(\mathrm{n}=85)$ and $\mathrm{t} 267(\mathrm{n}=31)$. Five of the 13 spa types were only found once each.

In 34 of 38 (89\%) cows with PER Staph. aureus infections, the same spa type was found at calving and 4 DIM. No distinctions in genotype patterns could be identified between CLE, NEW, and PER infections other than for one herd (D), where primiparous CLE and NEW infections $(\mathrm{n}=5)$ were caused by t529 and primiparous PER infections by t127 $(\mathrm{n}=1)$ and $\mathrm{t} 177$ $(\mathrm{n}=1)$.

From each herd, 5 to 23 isolates of Staph. aureus from 4 to 17 cows were genotyped (Table 5 ). In most herds, 2 or 3 spa types were identified, but in herd G all isolates were of the same spa type ( $\mathrm{t} 529)$, whereas 7 and 4 spa types were identified in herds $\mathrm{L}$ and $\mathrm{M}$, respectively. The spa type t529 was found in all herds, except in herds $\mathrm{F}$ and $\mathrm{J}$.

In most herds with isolates from cows of different parities, the same spa types were found in both primiparous and multiparous cows (Table 5). In 3 herds $(\mathrm{C}, \mathrm{D}$, and $\mathrm{H})$, all isolates from multiparous cows were of the same spa type (t529), whereas several spa types, including t529, were found in primiparous cows. The other herds had similar spa types in primiparous and multiparous cows, or did not have more than a few isolates from each parity group genotyped, making it difficult to discern a pattern.

Pulsotypes of Strep. dysgalactiae. Pulsedfield gel electrophoresis was performed on 125 Strep. dysgalactiae isolates and the results are presented in Supplementary Table S1 (http://dx.doi.org/10.3168/ jds.2015-9487). Three to twenty-three isolates per herd were genotyped, except for herd L, where none of the banding patterns could be interpreted.

In 35 of 39 cows with PER Strep. dysgalactiae infections, identical banding patterns were obtained at calving and 4 DIM. The 4 remaining cows had isolates of the same Strep. dysgalactiae cluster at calving and 4 DIM. No distinction in pulsotypes or clusters could be detected for the different infection types.

Pulsotype patterns within herd varied among herds. In most herds, isolates belonged to 1 to 3 clusters, and in all herds except $2(\mathrm{~F}$ and $\mathrm{M})$, isolates of the same pulsotype could be found in more than one cow. In one herd (D) a predominant pulsotype was identified (pulsotype Da1); it was isolated once or twice from 10 of 11 cows. The Strep. dysgalactiae isolate of the 11th cow in that herd was of the same cluster as the predominant pulsotype. In herds with isolates genotyped from both parity groups, isolates of the same cluster were found in both parity groups in all herds but one (M).

Pulsotyping of Strep. uberis. Pulsed-field gel electrophoresis was performed on 54 Strep. uberis isolates and the results are presented in Supplementary Table S1 (http://dx.doi.org/10.3168/jds.2015-9487). Two to twelve milk isolates of Strep. uberis were genotyped for 9 herds. More than one cluster was identified in all herds where isolates from more than one cow were genotyped.

In 8 of 11 cows with Strep. uberis PER infections, the same pulsotype could be identified at calving and 4 DIM. In the remaining 3 cows, isolates of the same cluster, but not of the same pulsotype, were identified at calving and 4 DIM.

In 3 herds ( $\mathrm{A}, \mathrm{K}$, and $\mathrm{M}$ ), the same pulsotype was never found in more than one cow, and in herds $\mathrm{K}$ and $\mathrm{M}$ the same cluster was never found in more than one cow. Overall, the same pulsotype was rarely found in more than 1 or 2 cows. However, in herd $\mathrm{H}$, one pulsotype was identified in 4 cows, and in herd $\mathrm{L}$ one pulsotype was found in 3 cows. In herds I and L, the same pulsotype was found in a primiparous cow and in a multiparous cow. In herds $\mathrm{H}$ and $\mathrm{L}$, where the same cluster or pulsotype could be found in more than 2 cows, no distinction in pulsotypes or clusters could be associated with the different infection types.

\section{DISCUSSION}

The patterns of IMI of Staph. aureus, Strep. dysgalactiae, and Strep. uberis at calving and 4 DIM varied among the herds. Infections also differed between primiparous and multiparous cows, and among seasons. 
LUNDBERG ET AL.

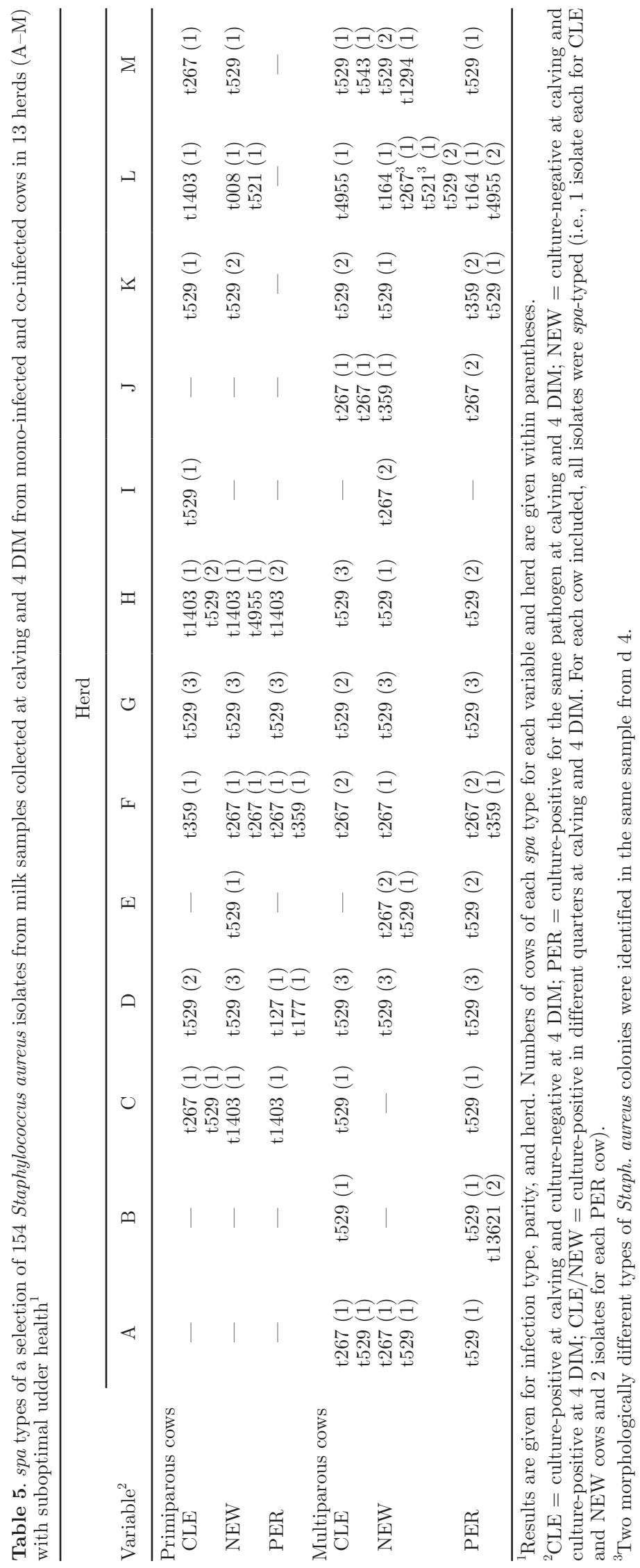


Intramammary infections of importance for udder health in early lactation were common at calving and 4 DIM. Overall, Staph. aureus was the most common of the 3 pathogens, followed by Strep. dysgalactiae and Strep. uberis. Staphylococcus aureus was also the most common pathogen in most of the herds, but in 3 herds one of the streptococci was the most frequently isolated pathogen. To our knowledge, herd studies following occurrence of these udder pathogens over time, including genotyping of isolates at and just after calving, have not been performed previously. The importance of the 3 pathogens are, however, in agreement with Norwegian and Swedish studies on CM during the first month of lactation (Waage et al., 1999; Persson Waller et al., 2009). Frequent findings of Staph. aureus and Strep. dysgalactiae IMI within a week after calving have also been reported from Norway (Whist et al., 2007, 2009). In other parts of the world, such as New Zealand, Strep. uberis is a common IMI found in the periparturient period (McDougall et al., 2004).

The relative distribution of CLE, PER, and NEW infections, illustrating if cows were infected only at calving, both at calving and 4 DIM, and only at 4 DIM, respectively, varied among pathogens and herds. Overall, PER infections were most common among Staph. aureus-infected cows, whereas CLE infections were most common among Strep. dysgalactiae- and Strep. uberisinfected cows. In almost all cows with PER infections the same genotype was found in both samplings, supporting the classification of those cows as persistently infected. The reasons for this difference between pathogens is not clear, but we hypothesized that differences in virulence factors were of importance, as it is well known that Staph. aureus often causes chronic IMI.

We also found differences between parities: PER Staph. aureus infections and Strep. uberis IMI at any of the 2 samplings were more common in multiparous cows than in primiparous ones. The infection status of multiparous cows at dry off was not known; thus, we could not establish whether the higher IMI prevalence in multiparous cows was due to chronic IMI originating in the previous lactation or if the infections occurred during the dry period. It has been suggested that an increased predisposition for new infections at calving is present in older cows, as the immune system of such cows is poorer than in primiparous cows in the periparturient period (Mehrzad et al., 2009). Differences in housing or other management factors for the 2 parity groups may also be factors of importance. Parity differences in prevalence of Strep. uberis IMI have been observed previously (Zadoks et al., 2001b); those authors concluded that the increased prevalence in multiparous cows was due, at least in part, to an increase in new infections rather than chronicity of infection. The fact that 10 to $15 \%$ of the primiparous cows in our study were infected with Staph. aureus or Strep. dysgalactiae at calving emphasizes the high risk for udder infections before first calving. A study from the United States has reported IMI before breeding and throughout the first gestation (Trinidad et al., 1990).

Some seasonal variation, especially for streptococcal IMI, was also identified. Overall, the proportion of Strep. dysgalactiae-infected cows was lowest in the early housing season (September to December), but the seasonal pattern of infection varied markedly between herds. In contrast, the lowest proportion of Strep. uber$i s$-infected cows was found during the pasture season (May to August), when all Swedish cows must be on pasture according to legislation. The seasonal pattern for Strep. uberis also varied among the herds, except for the 2 herds with the highest proportion of infected cows, where Strep. uberis was most common in the late housing season (January to April). The differences at herd level and the overall results emphasize the importance of not drawing general conclusions from limited material. The seasonal trend for Strep. dysgalactiae IMI was in line with a Norwegian study on IMI (Osterås et al., 2006). In contrast to our results, the highest prevalence of Strep. uberis IMI is instead found during summer (June and July) in the Norwegian study. In other parts of the world, udder infections with Strep. uberis are especially common in pasture-based systems (Compton et al., 2007).

Genotyping of the milk isolates gave important information for the interpretation of infection patterns within herds. Genotype information can also be used to assess possible transmission routes between herds. For example, one spa type (t529) of Staph. aureus was predominant and found in all but 2 herds. This spa type could be found in all infection types and among both primiparous and multiparous cows. Frequent occurrence of spa type t529 in bovine milk isolates has been reported in other European countries, as well as Japan and Canada (Hata et al., 2010; Said et al., 2010; Johler et al., 2011). Our results also showed withinherd variation in Staph. aureus spa types as a function of parity. In some herds, only one spa type was found among multiparous cows, whereas several spa types exist in primiparous cows. This suggests that the source of infection, at least in some farms, differs with respect to parity. A limited variation in Staph. aureus genotypes among Swedish herds has been reported previously (Lundberg et al., 2014a), consistent with the proposed contagious nature of the pathogen. However, in 12 of 13 herds in the current study, more than one spa type was found, and a few herds had more than 3 types. This within-herd variation is in line with other studies on within-herd genetic variation of milk isolates 
(Sabour et al., 2004; Capurro et al., 2010). The variation of genotypes in some herds, and findings of Staph. aureus in samples from body sites and the environment of both heifers and milking cows (Roberson et al., 1994; Capurro et al., 2010), indicate that Staph. aureus IMI may also originate in the environment.

Most Strep. dysgalactiae pulsed-field gel electrophoresis patterns were distinct for each herd. However, a recent study on isolates from a national survey on VTCM found identical, or almost identical, banding patterns in up to 13 herds each (Lundberg et al., 2014b). In most herds in the present study, the isolates belonged to a few clusters, but a variety of pulsotypes; however, multiple isolates with identical banding patterns were found in a few herds. Streptococcus dysgalactiae has often been considered an environmental pathogen (Todhunter et al., 1995; Gillespie et al., 1998), but in some reports Strep. dysgalactiae is suggested to be contagious (Fox and Gay, 1993; Barkema et al., 1999). The results of the current study, and those of a previous study (Lundberg et al., 2014b), suggest that Strep. dysgalactiae may act both as a contagious and as an environmental pathogen in Swedish herds.

None of the Strep. uberis genotypes was found in more than one herd (results not shown), which is in line with the results from a recent study on $\mathrm{CM}$ isolates (Lundberg et al., 2014b). As in other countries (Baseggio et al., 1997; McDougall et al., 2004; Lasagno et al., 2011), considerable genotype variation exists within most herds, indicating that the environment was the most likely source of infection. Nonetheless, the same pulsotype was found in more than one cow in 2 herds. Outbreaks of Strep. uberis infections with suspected contagious spread have been reported previously (Zadoks et al., 2001a).

As mentioned, we found different infection patterns and associations between patterns and parity and season within the herds studied, indicating differences in the spread of infections. For example, none of the primiparous cows in herd $\mathrm{E}$ was positive for any of the 3 pathogens at the day of calving, indicating that udder health management for heifers was good. In multiparous cows, however, PER Staph. aureus infections were common in the same herd. Moreover, around $25 \%$ of the primiparous cows and $20 \%$ of the multiparous ones had NEW Staph. aureus infections at 4 DIM. This indicates a quick spread of such infections during early lactation in herd E. In the same herd, infections with Strep. dysgalactiae and Strep. uberis only occurred during the pasture season, suggesting good disease control during the remainder of the year. In contrast, all bacteriologically positive primiparous cows in herd J had PER infections with Staph. aureus or Strep. dysgalactiae, and all of the multiparous cows had CLE and
PER infections. This indicates that udder infections occurred before calving.

The genotype results also showed distinct herd patterns. In herds D and G, almost all Staph. aureus isolates belonged to one spa type (t529), indicating that contagious spread between udders was most probable. Both herds were revisited 1 yr after the end of the study period and the same Staph. aureus spa type was found again in the milk from cows in early lactation, and it was also the most common spa type in samples taken from body sites and the environment of dry cows and heifers in late pregnancy (Lundberg, 2015). Taken together, it seems that infections with this strain could be a result of both contagious and environmental spread. Streptococcus dysgalactiae was also common in herd D, and almost all Strep. dysgalactiae isolates were of the same pulsotype. In addition, the same Strep. dysgalactiae pulsotype was found in body site samples of dry cows, but not in environmental samples, at the follow-up visit (Lundberg, 2015); this indicates direct spread between udders. In herd G, however, both Strep. dysgalactiae and, to some extent, Strep. uberis were common findings, but the genotypic variation within species was substantial, as would be the case for environmental pathogens. A completely different pattern of infections was observed in herd L, where Staph. aureus and Strep. uberis were both common. Large genotype variation was noted within species for both pathogens, indicating the environment as the main source of infection. Nevertheless, the same Strep. uberis pulsotype was found in 3 cows in this herd, indicating some contagious spread, or a common source in the environment. In some herds, only a few isolates of a specific pathogen were found. In those cases, interpretation of genotype patterns must be done with caution.

The overall goal of the study was to get a better understanding of infection patterns in herds with udder health problems due to Staph. aureus, Strep. dysgalactiae, and Strep. uberis IMI to improve control measures. Thus, only herds with suboptimal udder health and a history of CM caused by Staph. aureus and streptococci were included. Unfortunately, sufficient data were only available from 13 herds, but the results showed that the herds were well-suited for the goal. Despite the small number of herds included, the herd variation found indicates that general recommendations on how to prevent IMI might not be sufficient. Instead, control measures should be based on the status of each individual herd. We believe that the knowledge gathered may be of value for other farms with similar herd health problems both at the national and international level.

The study design was chosen to evaluate if pathogens of importance for udder health in early lactation were present already at calving, or if they entered the udder 
during the first days of lactation. One milk sample per udder quarter was taken at each sampling occasion. According to the National Mastitis Council, duplicate milk sampling at each sampling occasion would have been preferable (Oliver et al. 2004), but that was not possible for economical and practical reasons. Several publications have since shown that the use of a single quarter milk sample for diagnosis of IMI is often acceptable (Torres et al., 2009; Dohoo et al., 2011).

The associations between SCC and VTCM during the first month of lactation, as well as bacterial findings at calving or 4 DIM, confirmed the relevance of the defined infection types for udder health. When analyzing if bacterial findings were of importance for udder health in early lactation, only mono-infected cows were included. Co-infected cows were excluded to avoid misinterpretation of the data. In all other analyses, however, we included both mono-infected and co-infected cows, as co-infection was fairly common. All cases of co-infection included Staph. aureus, Strep. dysgalactiae, or Strep. uberis. Thus, these co-infected cows most likely played a role in the within-herd spread of infection. For the same reason, all infection types were included when describing infection patterns in herds, even though CLE Staph. aureus infections did not have a statistically significant effect on early lactation udder health.

\section{CONCLUSIONS}

Although only 13 herds were used in the present study, we found differences in herd infection patterns. Moreover, some differences were seen in infection patterns between parities and seasons. Recommendations for better udder health are generally based on the most common pathogen(s) found in the herd, rather than on herd-specific circumstances. The present study emphasizes the need to choose preventive strategies on the basis of the status of each individual herd. Genotyping gave much insight to how the infection patterns differed within and between herds. Genotyping of udder pathogens is not used routinely today. However, reasonably priced genotyping could be a good aid in resolving mastitis problems at herd level.

\section{ACKNOWLEDGMENTS}

The authors thank the farmers for participating in the study, the Swedish Research Council for Environment (Stockholm, Sweden), Agricultural Sciences and Spatial Planning (Formas, Stockholm, Sweden), and the Swedish Farmers' Foundation for Agricultural Research (Stockholm, Sweden) for funding of the project, as well as the Swedish Dairy Association/Växa Sverige (Stockholm, Sweden) for contributing data. Maria Persson and Sigbrit Matsson at the National Veterinary Institute are gratefully acknowledged for excellent laboratory work, as well as Mattias Myrenås for performing spa typing. Thanks also to Karin Östensson at the Swedish University of Agricultural Sciences for valuable input.

\section{REFERENCES}

Archer, S. C., F. Mc Coy, W. Wapenaar, and M. J. Green. 2014. Association between somatic cell count during the first lactation and the cumulative milk yield of cows in Irish dairy herds. J. Dairy Sci. 97:2135-2144. http://dx.doi.org/10.3168/jds.2013-7158.

Barkema, H. W., Y. H. Schukken, T. J. Lam, M. L. Beiboer, G. Benedictus, and A. Brand. 1999. Management practices associated with the incidence rate of clinical mastitis. J. Dairy Sci. 82:1643-1654. http://dx.doi.org/10.3168/jds.S0022-0302(99)75393-2.

Barkema, H. W., Y. H. Schukken, T. J. Lam, M. L. Beiboer, H. Wilmink, G. Benedictus, and A. Brand. 1998. Incidence of clinical mastitis in dairy herds grouped in three categories by bulk milk somatic cell counts. J. Dairy Sci. 81:411-419. http://dx.doi.org/10.3168/ jds.S0022-0302(98)75591-2.

Baseggio, N., P. D. Mansell, J. W. Browning, and G. F. Browning. 1997. Strain differentiation of isolates of streptococci from bovine mastitis by pulsed-field gel electrophoresis. Mol. Cell. Probes 11:349-354. http://dx.doi.org/10.1006/mcpr.1997.0126.

Bradley, A. J., K. A. Leach, J. E. Breen, L. E. Green, and M. J. Green. 2007. Survey of the incidence and aetiology of mastitis on dairy farms in England and Wales. Vet. Rec. 160:253-257.

Capurro, A., A. Aspán, H. Ericsson Unnerstad, K. Persson Waller, and K. Artursson. 2010. Identification of potential sources of Staphylococcus aureus in herds with mastitis problems. J. Dairy Sci. 93:180-191. http://dx.doi.org/10.3168/jds.2009-2471.

Compton, C.W.R., C. Heuer, K. Parker, and S. McDougall. 2007. Epidemiology of mastitis in pasture-grazed peripartum dairy heifers and its effects on productivity. J. Dairy Sci. 90:4157-4170. http:// dx.doi.org/10.3168/jds.2006-880.

Dohoo, I., W. Martin, and H. Stryhn. 2010. Veterinary Epidemiologic Research. 2nd ed. VER Inc, Charlottetown, Prince Edward Islands, Canada.

Dohoo, I. R., J. Smith, S. Andersen, D. F. Kelton, S. Godden, and Mastitis Research Workers' Conference. 2011. Diagnosing intramammary infections: Evaluation of definitions based on a single milk sample. J. Dairy Sci. 94:250-261. 10.3168/jds.2010-3559.

Douglas, V. L., S. G. Fenwick, D. U. Pfeiffer, N. B. Williamson, and C. W. Holmes. 2000. Genomic typing of Streptococcus uberis isolates from cases of mastitis, in New Zealand dairy cows, using pulsedfield gel electrophoresis. Vet. Microbiol. 75:27-41.

Ericsson Unnerstad, H., A. Lindberg, K. Persson Waller, T. Ekman, K. Artursson, M. Nilsson-Ost, and B. Bengtsson. 2009. Microbial aetiology of acute clinical mastitis and agent-specific risk factors. Vet. Microbiol. 137:90-97. http://dx.doi.org/10.1016/j. vetmic.2008.12.005

Fox, L. K., S. T. Chester, J. W. Hallberg, S. C. Nickerson, J. W. Pankey, and L. D. Weaver. 1995. Survey of intramammary infections in dairy heifers at breeding age and first parturition. J. Dairy Sci. 78:1619-1628. http://dx.doi.org/10.3168/jds.S00220302(95)76786-8.

Fox, L. K., and J. M. Gay. 1993. Contagious mastitis. Vet. Clin. North Am. Food Anim. Pract. 9:475-487.

Gianneechini, R., C. Concha, R. Rivero, I. Delucci, and J. Moreno López. 2002. Occurrence of clinical and sub-clinical mastitis in dairy herds in the West Littoral Region in Uruguay. Acta Vet. Scand. 43:221-230. 
Gillespie, B. E., B. M. Jayarao, J. W. Pankey, and S. P. Oliver. 1998. Subtyping of Streptococcus dysgalactiae and Streptococcus uberis isolated from bovine mammary secretions by DNA fingerprinting. Zentralbl. Veterinärmed. B 45:585-593.

Hallin, M., A. W. Friedrich, and M. J. Struelens. 2009. spa typing for epidemiological surveillance of Staphylococcus aureus. Pages XXXX in Molecular Epidemiology of Microorganisms; Methods and Protocols. Methods in Molecular Biology Vol 551. D. A. Caugant, ed. Humana Press, Totowa, NJ.

Hata, E., K. Katsuda, H. Kobayashi, I. Uchida, K. Tanaka, and M. Eguchi. 2010. Genetic variation among Staphylococcus aureus strains from bovine milk and their relevance to methicillinresistant isolates from humans. J. Clin. Microbiol. 48:2130-2139. http://dx.doi.org/10.1128/JCM.01940-09.

Johler, S., F. Layer, and R. Stephan. 2011. Comparison of virulence and antibiotic resistance genes of food poisoning outbreak isolates of Staphylococcus aureus with isolates obtained from bovine mastitis milk and pig carcasses. J. Food Prot. 74:1852-1859. http:// dx.doi.org/10.4315/0362-028X.JFP-11-192.

Lasagno, M. C., E. B. Reinoso, S. A. Dieser, L. F. Calvinho, F. Buzzola, C. Vissio, C. I. Bogni, and L. M. Odierno. 2011. Phenotypic and genotypic characterization of Streptococcus uberis isolated from bovine subclinical mastitis in Argentinean dairy farms. Rev. Argent. Microbiol. 43:212-217. http://dx.doi.org/10.1590/S032575412011000300009 .

Lundberg, A. 2015. Mastitis in dairy cows. Genotypes, spread, and infection outcome of three important udder pathogens. Doctoral thesis No. 2015:28, Acta Universitatis Agriculturae Sueciae, Swedish University of Agricultural Sciences, Uppsala, Sweden. http:// pub.epsilon.slu.se/11975/.

Lundberg, A., A. Aspán, A. Nyman, H. E. Unnerstad, and K. Persson Waller. 2014a. Associations between bacterial genotype and outcome of bovine clinical Staphylococcus aureus mastitis. Acta Vet. Scand. 56:2. http://dx.doi.org/10.1186/1751-0147-56-2.

Lundberg, Ă., A. Nyman, H. Unnerstad, and K. Persson Waller. 2014b. Prevalence of bacterial genotypes and outcome of bovine clinical mastitis due to Streptococcus dysgalactiae and Streptococcus uberis. Acta Vet. Scand. 56:80. http://dx.doi.org/10.1186/ s13028-014-0080-0.

Madouasse, A., J. N. Huxley, W. J. Browne, A. J. Bradley, and M. J. Green. 2010. Somatic cell count dynamics in a large sample of dairy herds in England and Wales. Prev. Vet. Med. 96:56-64. http://dx.doi.org/10.1016/j.prevetmed.2010.05.005.

McDougall, S., D. G. Arthur, M. A. Bryan, J. J. Vermunt, and A. M. Weir. 2007. Clinical and bacteriological response to treatment of clinical mastitis with one of three intramammary antibiotics. N. Z. Vet. J. 55:161-170. http://dx.doi.org/10.1080/00480169.2007. 36762 .

McDougall, S., T. J. Parkinson, M. Leyland, F. M. Anniss, and S. G. Fenwick. 2004. Duration of infection and strain variation in Streptococcus uberis isolated from cows' milk. J. Dairy Sci. 87:20622072. http://dx.doi.org/10.3168/jds.S0022-0302(04)70024-7.

Mehrzad, J., L. Duchateau, and C. Burvenich. 2009. Phagocytic and bactericidal activity of blood and milk-resident neutrophils against Staphylococcus aureus in primiparous and multiparous cows during early lactation. Vet. Microbiol. 134:106-112. http://dx.doi. org/10.1016/j.vetmic.2008.09.001

Mellmann, A., A. W. Friedrich, N. Rosenkötter, J. Rothgänger, H. Karch, R. Reintjes, and D. Harmsen. 2006. Automated DNA sequence-based early warning system for the detection of methicillin-resistant Staphylococcus aureus outbreaks. PLoS Med. 3:e33. http://dx.doi.org/10.1371/journal.pmed.0030033.

Mørk, T., T. Tollersrud, B. Kvitle, H. J. Jørgensen, and S. Waage, 2005. Comparison of Staphylococcus aureus genotypes recovered from cases of bovine, ovine, and caprine mastitis. J. Clin. Microbiol. 43:3979-3984. http://dx.doi.org/10.1128/JCM.43.8.39793984.2005 .

Myllys, V., and H. Rautala. 1995. Characterization of clinical mastitis in primiparous heifers. J. Dairy Sci. 78:538-545. http://dx.doi. org/10.3168/jds.S0022-0302(95)76664-4.
Nam, H. M., J. M. Kim, S. K. Lim, K. C. Jang, and S. C. Jung, 2010. Infectious aetiologies of mastitis on Korean dairy farms during 2008. Res. Vet. Sci. 88:372-374. http://dx.doi.org/10.1016/j. rvsc.2009.12.008

Olde Riekerink, R. G. M., H. W. Barkema, D. F. Kelton, and D. T. Scholl. 2008. Incidence rate of clinical mastitis on Canadian dairy farms. J. Dairy Sci. 91:1366-1377. http://dx.doi.org/10.3168/ jds.2007-0757.

Olde Riekerink, R. G. M., H. W. Barkema, and H. Stryhn. 2007. The effect of season on somatic cell count and the incidence of clinical mastitis. J. Dairy Sci. 90:1704-1715. http://dx.doi.org/10.3168/ jds.2006-567.

Oliver, S. P., R. N. Gonzalez, J. S. Hogan, B. M. Jayarao, and W. E. Owens, eds. 2004. Microbiological Procedures for the Diagnosis of Bovine Udder Infection and Determination of Milk Quality. 4th ed. National Mastitis Council, Verona, WI.

Osterås, O., L. Sølverød, and O. Reksen. 2006. Milk culture results in a large Norwegian survey - Effects of season, parity, days in milk, resistance, and clustering. J. Dairy Sci. 89:1010-1023. http://dx.doi. org/10.3168/jds.S0022-0302(06)72167-1.

Persson, Y., A.-K. J. Nyman, and U. Grönlund-Andersson. 2011. Etiology and antimicrobial susceptibility of udder pathogens from cases of subclinical mastitis in dairy cows in Sweden. Acta Vet. Scand. 53:36. http://dx.doi.org/10.1186/1751-0147-53-36.

Persson Waller, K., B. Bengtsson, A. Lindberg, A. Nyman, and H Ericsson Unnerstad. 2009. Incidence of mastitis and bacterial findings at clinical mastitis in Swedish primiparous cows- influence of breed and stage of lactation. Vet. Microbiol. 134:89-94. http:// dx.doi.org/10.1016/j.vetmic.2008.09.004.

Roberson, J. R., L. K. Fox, D. D. Hancock, J. M. Gay, and T. E. Besser. 1994. Ecology of Staphylococcus aureus isolated from various sites on dairy farms. J. Dairy Sci. 77:3354-3364. http://dx.doi. org/10.3168/jds.S0022-0302(94)77277-5.

Sabour, P. M., J. J. Gill, D. Lepp, J. C. Pacan, R. Ahmed, R. Dingwell, and K. Leslie. 2004. Molecular typing and distribution of Staphylococcus aureus isolates in Eastern Canadian dairy herds. J. Clin. Microbiol. 42:3449-3455. http://dx.doi.org/10.1128/ JCM.42.8.3449-3455.2004.

Said, K. B., J. Ismail, J. Campbell, M. R. Mulvey, A.-M. Bourgault, S. Messier, and X. Zhao. 2010. Regional profiling for determination of genotype diversity of mastitis-specific Staphylococcus aureus lineage in Canada by use of clumping factor A, pulsed-field gel electrophoresis, and spa typing. J. Clin. Microbiol. 48:375-386. http:// dx.doi.org/10.1128/JCM.01768-09.

Sommerhäuser, J., B. Kloppert, W. Wolter, M. Zschöck, A. Sobiraj, and K. Failing. 2003. The epidemiology of Staphylococcus aureus infections from subclinical mastitis in dairy cows during a control programme. Vet. Microbiol. 96:91-102.

Svensson, C., A.-K. Nyman, K. Persson Waller, and U. Emanuelson. 2006. Effects of housing, management, and health of dairy heifers on first-lactation udder Health in Southwest Sweden. J. Dairy Sci. 89:1990-1999. http://dx.doi.org/10.3168/jds.S00220302(06)72266-4.

Todhunter, D. A., K. L. Smith, and J. S. Hogan. 1995. Environmental streptococcal intramammary infections of the bovine mammary gland. J. Dairy Sci. 78:2366-2374. http://dx.doi.org/10.3168/jds. S0022-0302(95)76864-3.

Torres, A. H., P. J. Rajala-Schultz, and F. J. DeGraves. 2009. Diagnosis of intramammary infections at dry-off based on sampling strategy, epidemiology of pathogens, and agreement beyond chance. J. Vet. Diagn. Invest. 21:427-436.

Trinidad, P., S. C. Nickerson, and T. K. Alley. 1990. Prevalence of intramammary infection and teat canal colonization in unbred and primigravid dairy heifers. J. Dairy Sci. 73:107-114. http://dx.doi. org/10.3168/jds.S0022-0302(90)78652-3.

Valde, J. P., L. G. Lawson, A. Lindberg, J. F. Agger, H. Saloniemi, and O. Østerås. 2004. Cumulative risk of bovine mastitis treatments in Denmark, Finland, Norway and Sweden. Acta Vet. Scand. 45:201. http://dx.doi.org/10.1186/1751-0147-45-201. 
Waage, S., T. Mørk, A. Røros, D. Aasland, A. Hunshamar, and S. A. Odegaard. 1999. Bacteria associated with clinical mastitis in dairy heifers. J. Dairy Sci. 82:712-719. http://dx.doi.org/10.3168/jds. S0022-0302(99)75288-4.

Whist, A. C., O. Østerås, and L. Sølverød. 2007. Streptococcus dysgalactiae isolates at calving and lactation performance within the same lactation. J. Dairy Sci. 90:766-778. http://dx.doi.org/10.3168/jds. S0022-0302(07)71561-8.

Whist, A. C., O. Osterås, and L. Sølverød. 2009. Association between isolation of Staphylococcus aureus one week after calving and milk yield, somatic cell count, clinical mastitis, and culling through the remaining lactation. J. Dairy Res. 76:24-35. http://dx.doi. org/10.1017/S0022029908003592.
Zadoks, R. N., H. G. Allore, H. W. Barkema, O. C. Sampimon, Y. T. Gröhn, and Y. H. Schukken. 2001a. Analysis of an outbreak of Streptococcus uberis mastitis. J. Dairy Sci. 84:590-599. http:// dx.doi.org/10.3168/jds.S0022-0302(01)74512-2.

Zadoks, R. N., H. G. Allore, H. W. Barkema, O. C. Sampimon, G. J. Wellenberg, Y. T. Gröhn, and Y. H. Schukkent. 2001b. Cow- and quarter-level risk factors for Streptococcus uberis and Staphylococcus aureus mastitis. J. Dairy Sci. 84:2649-2663.

Zadoks, R. N., B. E. Gillespie, H. W. Barkema, O. C. Sampimon, S P. Oliver, and Y. H. Schukken. 2003. Clinical, epidemiological and molecular characteristics of Streptococcus uberis infections in dairy herds. Epidemiol. Infect. 130:335-349. 